\title{
Pelatihan dan Pendampingan Implementasi Aplikasi Kepegawaian Pada SMA PGRI Pagaralam Berbasis Web
}

\author{
Rahmad Hidayat ${ }^{1}$, Andri ${ }^{2}$, Darius Antoni ${ }^{3}$, Hadi Syaputra ${ }^{4}$ \\ Universitas Bina Darma Palembang \\ Email: andri@binadarma.ac.id
}

\begin{abstract}
The current use of the system at SMA PGRI Pagaralam uses excel and word applications. This is still felt to be ineffective because there is no system that supports these problems. Mentoring training for making personnel applications conducted at SMA PGRI Pagaralam aims to help manage employee data so that it is more effective. Software development is carried out using software engineering rules (software engineering). In software engineering theory there are several kinds of software development process models. This research uses the waterfall model. The water fall model or what is often called the Classic life cycle model shows software development sequentially and systematically. So that the results of the webbased PGRI Pagar Alam high school personnel application include a login system, type of PTK, subjects, leave letters, years of service and subject teachers.
\end{abstract}

Keywords: application, system, software engineering

\section{Pendahuluan}

\subsection{Analisis Situasi}

Perkembangan ilmu pengetahuan dan teknologi informasi telah meliputi masyarakat dunia saat ini. Sebagai bagian dari masyarakat dunia, kita tentunya tidak ingin ketinggalan teknologi informasi yang sedang berkembang khususnya bagi siswa dan guru di lingkungan SMA PGRI Pagaralam yang menginginkan informasi yang selalu up to date. SMA PGRI Pagaralam merupakan sekolah yang saat ini sedang mencoba melakukan terobosan yaitu dengan memanfaatkan teknologi informasi yang sedang berkembang pesat yang akan di terapkan pada SMA PGRI Pagaralam berupa aplikasi kepegawaian yang akan memudahkan bagi administrator sekolah di bagian Tata Usaha dalam menginputkan data-data yang berhubungan dengan administrasi kepegawaian. Menurut Kadir (2008:3) program aplikasi adalah program siap pakai atau program yang direka untuk melaksanakan suatu fungsi bagi pengguna atau aplikasi lain.

Aplikasi ini bermanfaat bagi admin sekolah karena lebih efisien dalam mengolah data baik data guru, karyawan dan siswa serta dapat langsung dilaporkan kepada kepala sekolah untuk pemantauan terhadap guru dan karyawan. Dengan aplikasi ini kepala sekolah dapat selalu melihat dan mendapatkan informasi mengenai perkembangan apa saja atau hal apa saja yang terjadi dalam kurun waktu tertentu. Serta juga akan memudahkan kepala sekolah apabila menghadiri rapat-rapat dinas yang berhubungan dengan sekolah, dengan data-data yang telah 
disediakan oleh aplikasi maka kepala sekolah cukup dengan mengakses aplikasi dan dapat dilakukan di manapun dengan perangkat keras yang mempunyai koneksi dengan internet.

Kegiatan pengabdian masyarakat untuk membuat aplikasi kepegawaian di SMA PGRI Pagaralam dilaksanakan oleh tim dosen dan mahasiswa. Tujuan dari kegiatan pengabdian ini untuk membantu pihak sekolah dalam membuat sebuah aplikasi yang nantinya dapat membantu dalam pengolahan data pegawai yang ada dilingkungan SMA PGRI Pagaralam.

\subsection{Permasalahan Mitra}

Saat ini dalam proses pengolahan data kepegawaian yang ada SMA PGRI Pagaralam masih terbatas menggunakan aplikasi office Microsoft Excel. Penggunaan aplikasi ini memiliki kekurangan seperti akses terbatas, dikarenakan aplikasi tidak bisa diakses secara online. Penggunaan aplikasi Microsoft Excel juga terbatas jika data yang disimpan terlalu besar.

\section{Solusi Masalah}

Berdasarkan permasalahan yang dihadapi oleh SMA PGRI Pagaralam maka akan dibuatkan sebuah aplikasi komputer yang dapat digunakan untuk mengolah data pegawai berbasis web. Aplikasi kepegawaian yang berbasis web mempunyai keuntungan dapat diakses secara online oleh admin ataupun kepala sekolah. Menurut Sibero (2013:11) web adalah suatu sistem yang berkaitan dengan dokumen digunakan sebagai media untuk menampilkan teks, gambar, multimedia dan lainnya pada jaringan internet.

\section{Metode Pelaksanaan}

Bentuk kegiatan pengabdian masyarakat yang dilakukan adalah berupa pelatihan dan pendampingan implementasi aplikasi kepegawaian berbasis web. Metode yang digunakan adalah seminar sehari, berupa diskusi dan tanya jawab serta pendampingan dalam implementasi aplikasi kepegawaian kepada admin yang akan menggunakan sistem tersebut.

Jumlah peserta yang hadir dalam acara kegiatan pengabdian masyarakat ini sebanyak 10 orang dari pihak sekolah yang berkepentingan dengan sistem aplikasi kepegawaian yang akan dibuat. Peserta dari kegiatan ini adalah kepala sekolah, guru serta pegawai yang ada di SMA PGRI Pagaralam. Dalam kegiatan yang dilakukan terbagi menjadi beberapa tahapan yaitu:

a. Tahapan Persiapan

Kegiatan pengabdian masyarakat ini bertujuan untuk membantu pihak sekolah untuk membuat sebuah aplikasi kepegawaian yang dapat digunakan oleh pihak sekolah dalam mengolah data pegawai yang efisien. Persiapan yang dilakukan dalam kegiatan pengabdian masyarakat ini adalah mengetahui kebutuhan sistem yang diharapkan oleh pihak sekolah.

b. Tahapan Pelatihan

Dalam tahapan ini dilakukan pelatihan secara singkat dalam pembuatan aplikasi kepegawaian. Dalam kegiatan ini diberikan pelatihan cara penggunaan aplikasi kepegawaian. Peserta yang terlibat dalam pelatihan ini adalah pegawai yang nantinya bertugas sebagai admin untuk mengelola sistem yang telah dibuat.

c. Tahapan Pendampingan

Pada tahapan ketiga dalam kegiatan pengabdian masyarakat ini adalah pendampingan dari tim kepada admin sekolah cara penggunaan aplikasi kepegawaian yang telah dibuat. Kegiatan ini bertujuan untuk memberikan pendampingan kepada admin jika terjadi kendala dalam penggunaan sistem yang ada. Kegiatan pendampingan ini dilakukan selama 1 minggu sehingga admin yang bertugas benar-benar paham dalam mengelola sistem aplikasi yang telah dibuat sehingga dapat bermanfaat bagi pihak sekolah. 


\section{Hasil Pelaksanaan dan Diskusi}

\subsection{Pelatihan}

Pelatihan pembuatan aplikasi kepegawaian ini dilakukan untuk membantu pihak sekolah untuk membuat aplikasi yang dapat digunakan untuk mengolah data pegawai dilingkungan SMA PGRI Pagaralam. Dalam pembuatan aplikasi menggunakan metode waterfall. Model waterfall atau yang sering disebut model Classic life cycle menunjukkan pengembangan perangkat lunak secara berurutan dan sistematimatis. Menurut Pressman (2015:42), model waterfall adalah model klasik yang bersifat sistematis, berurutan dalan membangun software. Model ini dapat dilihat pada gambar berikut:

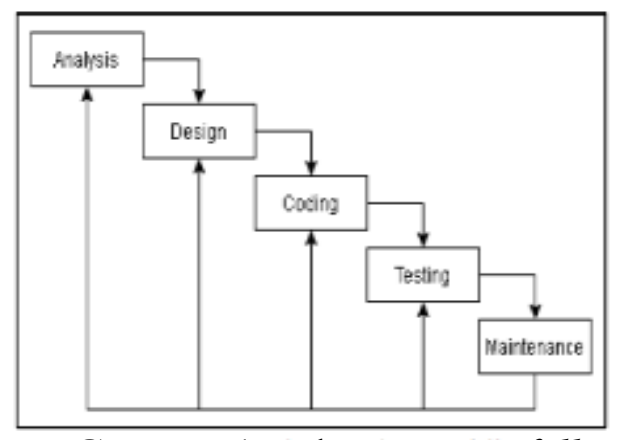

Gā̄mbar 1: Tahapàn Wäterfall

a. Tahap Analisis

Selama melakukan kegiatan pengabdian masyarakat di SMA PGRI Pagaralam, tim menganalisa kebutuhan sistem yang diminta oleh pihak sekolah untuk membuat sistem kepegawaian yang dapat membantu mengelola data pegawai sehingga lebih efektif. Kebutuhan untuk sistem kepegawaian yang akan dikembangkan SMA PGRI Pagaralam meliputi sistem login, jenis PTK, mata pelajaran, surat cuti, masa kerja dan pengajar mata pelajaran

\section{b. Tahap Design}

Pada design atau perancangan yang dilakukan terdapat dua diagram yaitu Use Case Diagram dan Activity Diagram. Pada tahap design ini juga terdapat desain class diagram, desain database Tabel user digunakan untuk menyimpan data user yang berhak menggunakan sistem. Tabel Jenis PTK, Tabel jenis PTK digunakan untuk menyimpan data jenis PTK yang ada disekolah SMA PGRI Pagaralam. Tabel pegawai digunakan untuk menyimpan data pegawai yang ada disekolah SMA PGRI Pagaralam. Tabel cuti digunakan untuk menyimpan data cuti pegawai yang ada disekolah SMA PGRI Pagaralam. Tabel mata pelajaran digunakan untuk menyimpan data mata pelajaran yang ada disekolah SMA PGRI Pagaralam. Tabel pengajar mata pelajaran digunakan untuk menyimpan data guru yang mengasih mata pelajaran yang ada disekolah SMA PGRI Pagaralam.

c. Tahap Coding

Tahap selanjutnya yaitu coding merupakan tahapan menterjemahakn hasil dari desain ke dalam Bahasa pemograman. Untuk membuat aplikasi tim menggunakan Bahasa pemograman $P H P$ dan $H T M L$ serta database yang digunakan adalah MySQL. 


\subsection{Pendampingan}

Setelah tahapan pelatihan pembuatan aplikasi kepegawaian dan peserta pelatihan mendapatkan materi dan pemahaman yang baik dalam pembuatan aplikasi kepegawaian, langkah selanjutnya adalah pendampingan dalam penggunaan aplikasi kepegawaian yang telah dibuat. Pendampingan ini bertujuan untuk membantu pegawai yang ditunjuk sebagai admin oleh sekolah untuk mengelola aplikasi yang telah dibuat.

Tim pengabdian masyarakat melakukan pendampingan dalam penggunaan aplikasi sehingga admin yang bertugas dapat menguasai dalam penggunaan aplikasi kedepannya. Aplikasi kepegaiawan ini terdiri dari beberapa halaman menu, yaitu halaman login, halaman menu utama admin, halaman jenis PTK, halaman data pegawai, halaman cuti pegawai, halaman pengajar dan mata pelajaran dan laporan.

a. Form Login

merupakan form awal pembuka dari aplikasi kepegawaian pada SMA PGRI Pagaralam sebelum masuk ke menu utama.

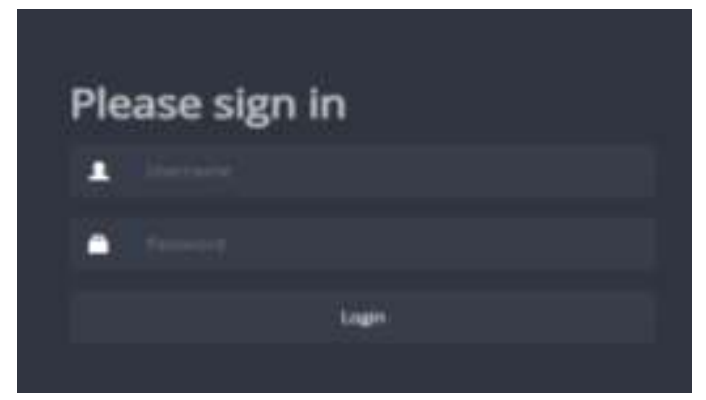

b. Menu Utama Admin

Gambar 2: Form Login

Menu Utama Admin merupakan tampilan yang digunakan admin untuk mengelola data pada aplikasi kepegawaian SMA PGRI Pagaralam.

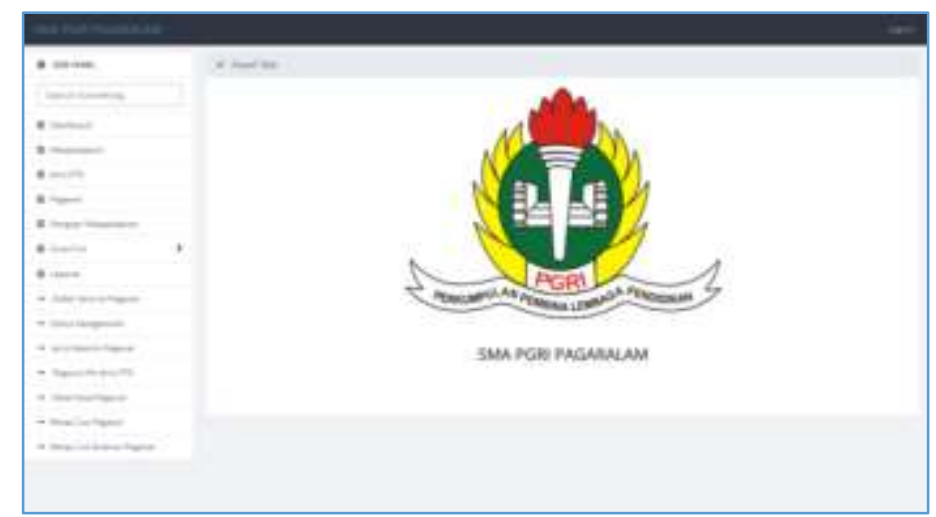

Gambar 3: Menu Utama

c. Halaman Jenis PTK

Halaman jenis PTK digunakan untuk menginput jenis PTK yang ada di SMA PGRI Pagaralam. Jenis PTK yang terdapat di SMA PGRI Pagaralam adalah Guru Mata pelajaran dan Tenaga Adminitrasi. 


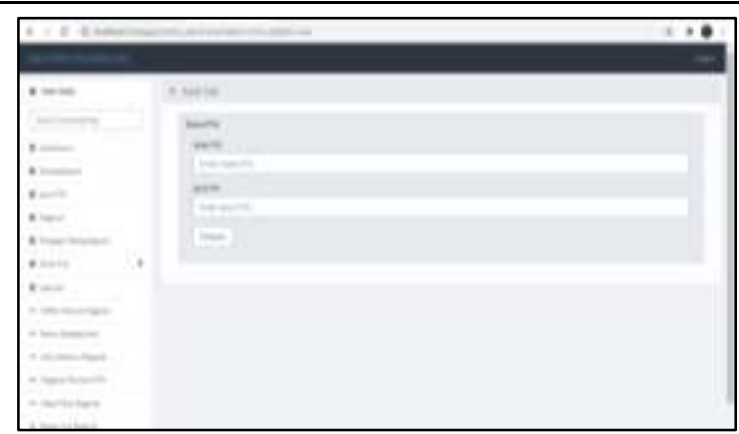

Gambar 4: Halaman PTK

d. Halaman Data Pegawai

Halaman data pegawai digunakan oleh admin untuk mendata pegawai yang ada di lingkungan SMA PGRI Pagaralam. Data pegawai yang diisi kan dimulai dari NUPTK, Nama Pegawai Jenis Kelamin, Tanggal Lahir,Tempat Lahir, TMT Kerja, Pendidikan Terakhir, Prodi Lulusan dan unit PTK.

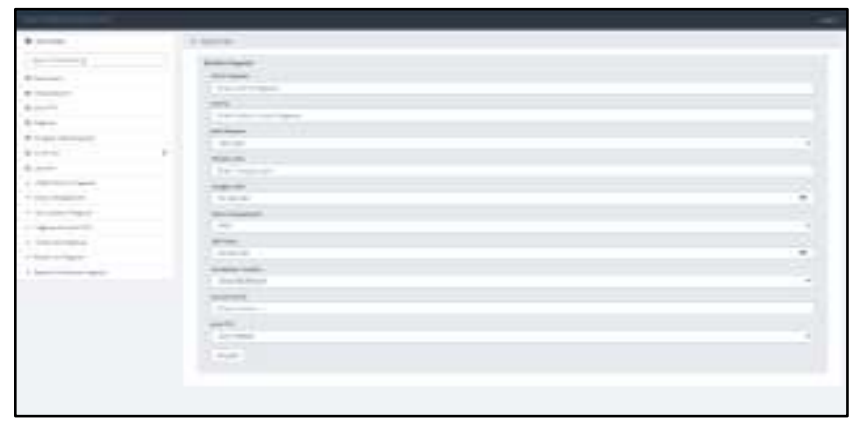

Gambar 5: Halaman Data Pegawai

e. Halaman Cuti Pegawai

Halaman cuti pegawai digunakan untuk menginput data pegawai yang cuti di SMA PGRI Pagaralam. Pada halaman cuti pegawai, admin akan memasukkan data Nama Pegawai, NUPTK Jenis Cuti.

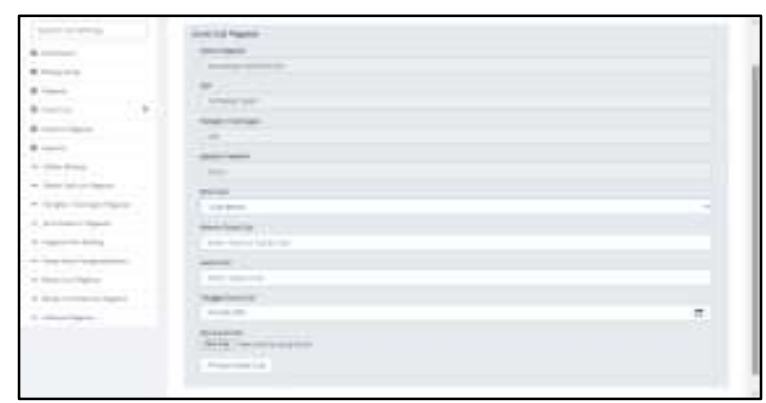

Gambar 6: Halaman Cuti Pegawai

f. Halaman Pengajar dan Mata Pelajaran

Halaman pengajar Mata pelajaran digunakan untuk menginput data pengasuh mata pelajaran SMA PGRI Pagaralam. 


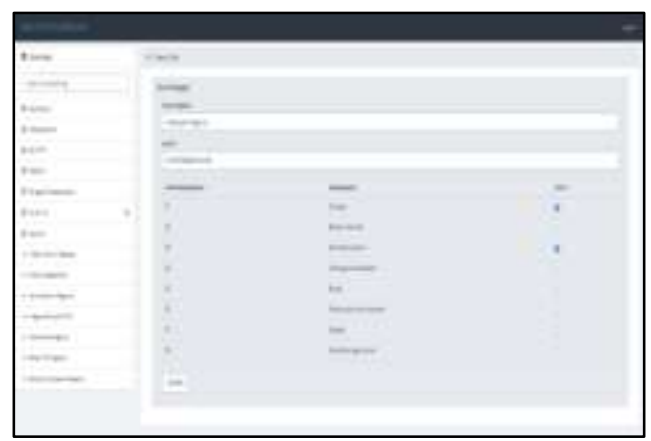

Gambar 7:Halaman Pengajar dan Mata Pelajaran

Pada halaman rekap absensi bulanan pegawai, admin mengisikan jumlah masuk dan tidak masukdari masing-masing pegawai

g. Laporan Data Pegawai

Laporan seluruh pegawai merupakan laporan yang menampilkan seluruh pegawai di SMA PGRI Pagaralam

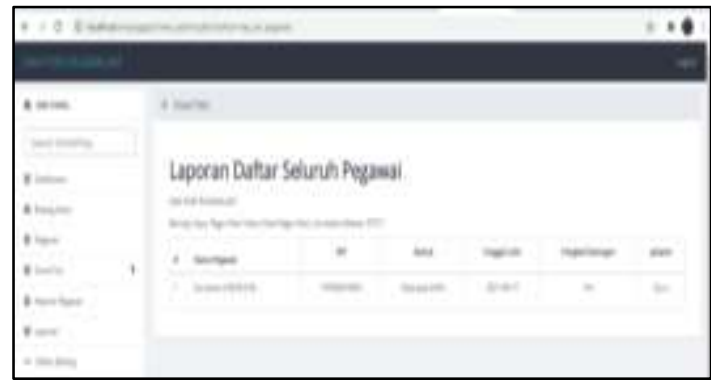

Gambar 8: Laporan Data Pegawai

Melalui kegiatan pelatihan dan pendampingan yang dilakukan pegawai yang ditugaskan oleh pihak sekolah dalam mengelola aplikasi yang telah dibuat diharapkan dapat menguasai cara singkat pembuatan dan pengelolaan aplikasi kepegawaian berbasis web. Aplikasi kepegawaian yang telah dibuat dapat digunakan oleh pihak sekolah untuk mengolah data pegawai yang ada dilingkungan sekolah SMA PGRI Pagaralam.।

\section{Kesimpulan}

Program kegiatan pengabdian masyarakat berupa pelaksanaan pelatihan dan pendampingan telah diselenggarakan dengan baik dan berjalan lancar sesuai dengan rencana kegiatan yang telah dibuat sebelumnya. Kegiatan pengabdian masyarakat ini telah mendapat sambutan baik dari pihak sekolah. Kegiatan PKM ini dapat membantu pihak sekolah dalam mempermudah pengolahan data kepegawaian yang ada dilingkungan sekolah SMA PGRI Pagaralam. Dengan adanya aplikasi yang telah dibuat diharapkan pihak sekolah dapat memanfaatkan dengan baik.
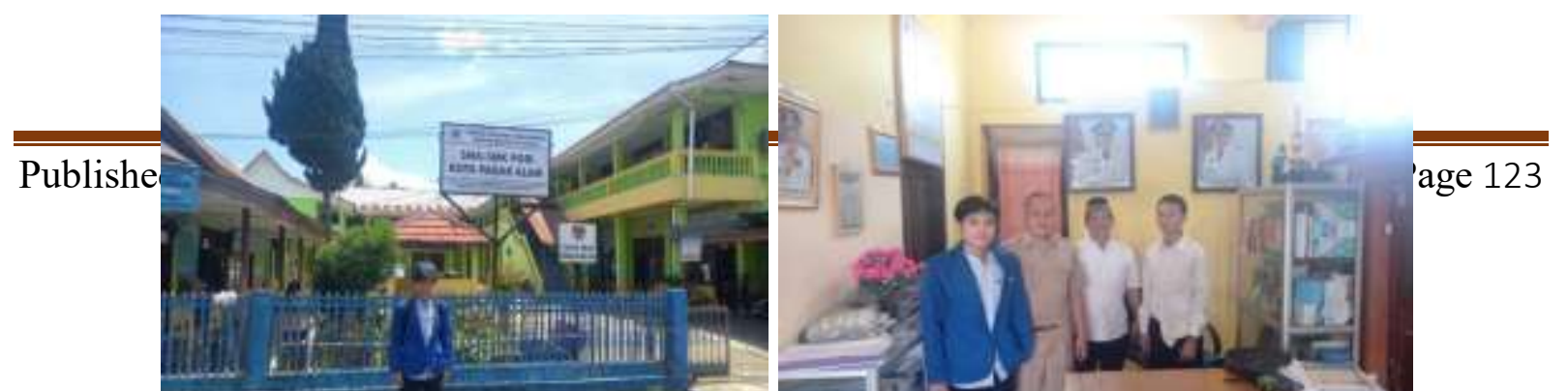
Gambar 9: Lokasi PKM

\section{Daftar Pustaka}

Kadir, Abdul. (2008). Membuat Aplikasi Web dengan PHP dan Database MySQL. Andi: Yogyakarta.

Sibero, Alexander F.K. (2013). Web Programming Power Pack. MediaKom:Yogyakarta

Pressman, R.S. (2015). Rekayasa Perangkat Lunak:Pendekatan Praktis Buku I. Andi:Yogyakarta.

\section{Copyrights}

Copyright for this article is retained by the author(s), with first publication rights granted to the journal.

This is an open-access article distributed under the terms and conditions of the Creative Commons Attribution license (http://creativecommons.org/licenses/by/4.0/) 